
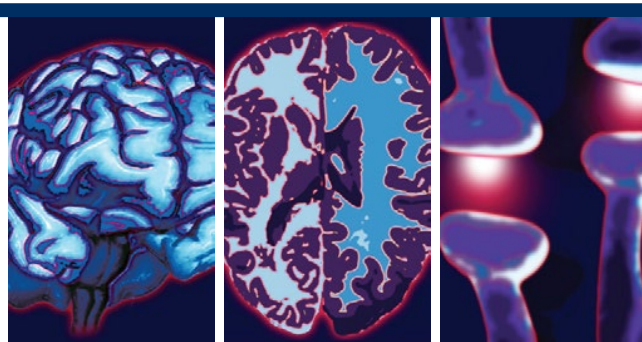

\title{
Post Stroke Depression Frequently Overlooked, Undiagnosed, Untreated
}

\author{
Sabrina K Dar ${ }^{1}$, Hema Venigalla ${ }^{2}$, Ali Mahmood Khan ${ }^{1, \dagger}$, Rizwan Ahmed $^{3}$, Hema Madhuri Mekala ${ }^{4}$, Hira Zain ${ }^{5}$, Shanila \\ Shagufta'
}

\begin{abstract}
Depression is the most frequently seen neuropsychiatric manifestation in stroke patients. It hampers the ability to undergo therapy and impairs their functional outcome. Depression also increases the risk of suicide in stroke patients, therefore, increasing mortality. The etiology of post-stroke depression (PSD) is complex and reported to be multi-factorial in origin. It also depends on the size and location of the infarct. In addition, family history or prior history of depressive disorders makes them prone to be affected with depression following a stroke. In this article, we will mention various aspects of PSD, as well as the prevalence and the different screening assessment tools used in literature studies. Although there are many available testing tools, little consistency was seen in them being valid or reliable. We will also discuss the pathophysiology of depression in stroke patients with various available options for managing the condition. We will briefly review the use of alternative treatment such as Electroconvulsive therapy (ECT) and Transcranial Magnetic Stimulation (TMS) as well. However, we need further evidence-based research exploring the screening tool; i.e. universally acceptable for PSD and implementing an effective, non-invasive treatment modality impacting the prognosis. Also, we require further investigations to identify the role of antidepressants in the recovery of stroke patients.
\end{abstract}

\section{Keywords:}

Stroke, Post-stroke depression, Stroke location, Assessment and Treatment, Post-stroke Depression, Prevalence of PSD, Pathology in PSD, Mood disorders in PSD, Symptoms and diagnosis criteria in PSD, Assessment scales in PSD, Pharmacotherapy and other treatments in PSD, Depression in stroke survivors

\section{Methodology \\ A search for relevant published literature was performed using PubMed, Google Scholar. The keywords and phrases used included: Stroke lesion, post stroke depression, major depression, Post stroke symptoms, assessment and treatment. Other relevant studies were found by a review}

of the primary studies obtained in the search as well as reference tracing of selected articles. The inclusion and exclusion criteria were: Any articles that reported the symptomatology, pathophysiology, evaluation and treatment of post stroke depression. All research studies which were published in English language from

\footnotetext{
'Kings County Hospital Center, New York, USA

${ }^{2}$ Texas Behavioral Health, Texas, USA

${ }^{3}$ Liaquat College of Medicine and Dentistry, Karachi, Pakistan

${ }^{4}$ Griffin Memorial Hospital, Oklahoma, USA

${ }^{5}$ Dow University of Health Sciences, Karachi, Pakistan
}

${ }^{\dagger}$ Author for correspondence: Ali Mahmood Khan, Kings County Hospital Centre, New York, USA, Tel: 4088381189; email: ali_mahmood_ khan@hotmail.com 
the years 1977-2017 were included. Specific case studies, case letters, and grey literature as well as studies not published in English were excluded. By the end of the literature search, 135 articles met the inclusion criteria, excluding duplicates and pertained to the topic. Relevance was based on the individual article and abstract review conducted by an independent researcher. These 135 articles were used to extract qualitative data and summarize the findings.

\section{Introduction}

Stroke or cerebrovascular accident (CVA) is a severe medical condition with various adverse consequences. It is among one of the leading causes of disability in the United States. Currently, more than 6.5 million people with stroke reside in the United States. Poststroke depression (PSD) is one of the most common behavioral complications after a stroke, especially acute ischemic stroke [1]. About one in every third stroke patient suffers from depression [2]. According to Diagnostic and Statistical Manual (DSM) V, PSD is a mood disorder superimposed from another medical condition; i.e. stroke with features of depression, mania, or mixed symptoms [3]. Depression is more common in the setting of stroke than any other physical illness with the same level of disability [4]. The diagnosis of PSD requires having either depressed mood or loss of interest in previously pleasurable activities, along with two to four of other symptoms of depression occurring for at least two weeks [3]. Somatic symptoms and cognitive deficits make the diagnosis of PSD complex and often might require experienced clinical judgment.

However, it remains unclear about the etiology and pathophysiology of the depression in the setting of a stroke, with various studies reporting different mechanisms. The stroke involving neural circuits which regulate mood leading to depression is one such mechanism [5,6]. Other studies reported the association between poststroke psychological stress factors and depression $[7,8]$.

Robinson, et al. described the depression in the setting of stroke as due to the depletion of monoamine [9]. PSD may also seem to occur depending on the location of the infarct, commonly associating with the left anterior lobe and left basal ganglia lesions [10,11].

\section{Prevalence}

On average for every 40 seconds, there is a stroke case in the United States - around 600.000 new stroke cases are evident every year [12,13]. Based on the literature studies, there is variability in data reported about PSD prevalence. These differences are usually due to the variations in criteria used to diagnose PSD and the difference in age of patients studied. The higher prevalence was seen in hospital-based settings rather than community-based settings [14].

While several clinicians use DSM-III and DSMIV criteria to reach the diagnosis of PSD, some use a different kind of scales or questionnaires. Also, different clinicians have different cut-off scores for the same scale or questionnaire to define the diagnosis of PSD. It is also important to keep in mind that these levels are mostly used to assess the severity of depression and were not made to diagnose it. Due to these methodological issues, it is quite arduous to reach a conclusion about the real prevalence of PSD. Robinson, et al. reported that around 30\% stroke survivors experienced depressive symptoms six months later, if not immediately after stroke [15].

In 2005, a meta-analysis study that included 51 observational studies all over the world examined patients in different settings (hospital and rehabilitation). The study reported a pooled estimate indicating that depressive symptoms are present in $33 \%$ ( $95 \%$ CI, $29 \%$ to $36 \%)$ of all stroke survivors during follow-up irrespective of duration [16].

The most recent meta-analysis published in 2014, reported data from 61 observational studies, and included 25.488 patients from different geographical areas. According to the study, it is evident that $31 \%$ (95\% CI 28 to $35 \%$ ) of stroke survivors had depressive symptoms up to five years following a stroke [17]. The difference between these two meta-analyses is not significant, which raises concern about the underestimation of PSD.

Indeed, some co-existing factors might predispose the patients to PSD after stroke. The previous history of depression acts as a predecessor for PSD. Female gender, older age and physical disability following a severe stroke are considering factors as well. Hence, it would be wise for the physicians to keep in mind these factors, while evaluating the stroke patients.

Post stroke depression is considered the worst prognostic factor for the patients return to 
work [18]. However, PSD is often overlooked and its significance regarding stroke outcomes is frequently ignored and underestimated [19]. Despite the increasing number of studies investigating the prevalence, pharmacology, pathogenesis, risk factors, prevention and management, the net results of these studies are inconsistent [20,21]. There are no established conclusions in relation to its etiology and predictors and, consequently, regarding prevention and treatment procedures. PSD can interfere with recovery of the patients, affecting their quality of life, prolonging their rehabilitation and even causing mortality.

\section{Pathophysiology}

The pathophysiology of PSD depends on the extent and the location of CVA. Nonetheless, it is also rather difficult to differentiate between PSD and the grief in stroke survivors, especially in the first few weeks after stroke. Stroke is a sudden catastrophe, which may initiate both grieving processes and can lead to depressive symptoms. However, sadness or grief after stroke has an etiology and is an emotional feeling that cannot be sensed by those with depression [22]. One such distinguishing factor is depressed patients lack their identity in comparison to sadness. Few studies reported the evidence of depression in patients with anosognosia that makes a possible connection between stroke and depression. As these patients have no insight of their disability, they may not experience a psychological reaction following a stroke $[23,24]$.

In a similar way, the relation between silent ischemic stroke and vascular depression (i.e. late-onset depression) suggest that depression can also occur without any warning signs - the lesions being smaller make them less aware. Vascular depression is highly associated with ischemic lesions in striatal-frontal circuits that regulate mood. A study found patients with stroke having a smaller amygdala, especially in cognitive impairment patients. They reported that smaller amygdala from ischemic changes of stroke increases their vulnerability to depression [25]. There also seems to be an association between white matter hyperintensities with depression and executive dysfunction on T2 weighted MRI. It suggests the interruption in basal ganglia-prefrontal pathway mechanisms leading to PSD [26-67] (Tables 1-5).

\section{Post-stroke Depression and Lesion Location}

\section{- Symptomatology and diagnosis}

Depressive disorders are the most frequently unrecognized and maltreated disorders. Hence, it complicates the diagnosis of depression following occurrences of a stroke even more. Depression in the setting of a stroke can have various health impacts on cognition, along with the loss of concentration, impairment in new learning skills, and motor functioning deficits collectively termed as depressive-executive dysfunction syndrome (DES) [27,68]. Although the risk of depression proportionately decreases with age in a general population, it almost doubles the risk in stroke patients [69]. The onset and the course of depression in stroke patient also vary from patient to patient with resolving typically in 1 to 2 years, but it can chronically persist to more than three years [70]. Studies suggest that if the onset is within few days post stroke, then the chances of spontaneous remission are likely high. The recovery opportunities are minimal if the onset is more than seven weeks [71]. According to a study, the discrepancy in results with community centre patients was little depressed than hospitalized or inpatient rehabilitated patients, because of the greater disability in the latter subjects. It further proves that there is an interdependent relationship between the depression and the functional impairment [72,73].

Previous studies also indicate two types of depressive disorders associated with cerebral ischemia: major depression in about 25\% patients and minor depression in approximately $30 \%$ patients [44]. A minor depression is a mood disorder characterized by the lack of interest and at least two, but less than four of the other main depressive symptoms [3]. The prevalence of minor depression in stroke patients is estimated around $22 \%$ after two months [74] and $8 \%$ after four months [1].

Diagnosis of depression in stroke patients can be made with various assessments, starting with the symptoms of depression such as depressed mood, anhedonia, lack of sleep, appetite, and concentration, sense of worthlessness and suicidality. Apart from that, diagnosis of PSD requires comprehensive interviews and rating scales by adequately trained health care professionals. However, it is crucial to assess depression in stroke survivors with superimposed aphasia, anosognosia, and cognitive deficits. These conditions need to be monitored carefully 
Review Ali Mahmood Khan

\begin{tabular}{|c|c|c|c|}
\hline A Authors s & $\begin{array}{l}\text { Number of } \\
\text { patients a }\end{array}$ & Location of stroke & Relation to depression severity \\
\hline M. Sharpe, et al. 1990 [28] & 60 & $\begin{array}{l}\text { Left hemisphere } 51 \% \text { Right hemisphere } \\
49 \%\end{array}$ & No relation \\
\hline Andersen G, et al. 1995 [29] & 285 & Right and left hemisphere lesions & Major depression was unrelated to lesion location \\
\hline Herrmann M, et al. 1995 [30] & 104 & Right and left hemisphere lesion. & $\begin{array}{l}\text { Left hemisphere basal ganglia lesions are significantly } \\
\text { related to development of major depression }\end{array}$ \\
\hline lacoboni M, et al. 1995 [31] & 20 & Right and left hemisphere lesions & $\begin{array}{l}\text { Depression was significantly associated with dorsal lesions } \\
\text { in the right-hemisphere and anterior lesions in the left } \\
\text { hemisphere }\end{array}$ \\
\hline Bjerg Bendsen B, et al. 1997 (32) & 128 & Right or left hemisphere & Not mentioned \\
\hline Paolucci S, et al. 1999 [33] & 470 & Right and left hemisphere lesions & No association was found to site of lesion \\
\hline Shimoda K, et al. 1999 [34] & 60 & Right and left hemisphere lesions & $\begin{array}{l}\text { In-hospital depression was significantly associated with } \\
\text { left anterior hemisphere } \\
\text { At short follow up, depression was associated with frontal } \\
\text { lobe whether in right or left hemispheres }\end{array}$ \\
\hline Fuentes B, et al. 2009 [35] & 85 & Right and left side infarctions & No significant influence on severity \\
\hline Jiang XG, et al. 2014 [36] & 329 & Left and right hemisphere lesions & $\begin{array}{l}\text { Stroke survivors with left hemisphere of the brain and } \\
\text { more lesions }(\geq 2) \text { have more chance to get the PSD }\end{array}$ \\
\hline
\end{tabular}

Table 2: Studies investigating lesions located in the left cerebral hemisphere.

\begin{tabular}{|l|l|l|l|}
\hline Authors & $\begin{array}{l}\text { Number of } \\
\text { patients }\end{array}$ & Location of stroke & Relation to depression severity \\
\hline Starkstein SE, et al. 1991 [37] & 151 & Left frontal or left basal ganglia lesions & $\begin{array}{l}\text { Patients had a significantly higher frequency and severity } \\
\text { of depression }\end{array}$ \\
\hline Monica Astrom, et al. 1993 [38] & 80 & Left anterior brain lesions & $\begin{array}{l}\text { Left anterior brain lesion was a significant predictor for an } \\
\text { immediate major depression }\end{array}$ \\
\hline $\begin{array}{l}\text { José L. González Torrecillas, et al. } \\
\text { 1995 [39] }\end{array}$ & 37 & Anterior lesion and left hemisphere & More frequent prevalence of depression \\
\hline Kase CS, et al. 1998 [40] & 74 & Large left sided stroke & Post stroke decline in cognitive functions \\
\hline Berg A, et al. 2001 [41] & 100 & Left hemisphere or brainstem lesions & Stroke severity was associated with depression \\
\hline Nishiyama Y, et al. 2010 [42] & 134 & Left lenticulocapsular infarction & $\begin{array}{l}\text { Statistically significant independent predictor of } \\
\text { depression }\end{array}$ \\
\hline Rajashekaran P, et al. 2013 [43] & 62 & $\begin{array}{l}\text { Left sided cortical infarcts and sub } \\
\text { cortical infarcts }\end{array}$ & They showed statistically significant association with PSD. \\
\hline Alajbegovic A, et al. 2014 [44] & 210 & Stroke in the medial left hemisphere & PSD is more frequent \\
\hline
\end{tabular}

Table 3: Studies investigating lesions located in the right cerebral hemisphere.

\begin{tabular}{|l|l|l|l|}
\hline Authors & $\begin{array}{l}\text { Number of } \\
\text { patients }\end{array}$ & Location of stroke & Relation to depression severity \\
\hline MacHale SM, et al. $1998[45]$ & 55 & Right cerebral hemisphere & $\begin{array}{l}\text { Depression was significantly associated with larger lesions } \\
\text { involving the right cerebral hemisphere }\end{array}$ \\
\hline Mutai H, et al. 2017 [46] & 101 & $\begin{array}{l}\text { Right side lesion, thalamic and } \\
\text { brainstem lesion }\end{array}$ & $\begin{array}{l}\text { Stroke location was independently associated with } \\
\text { multidimensional aspects of PSF }\end{array}$ \\
\hline
\end{tabular}

with proper assessment tools to increase diagnostic accuracy [75]. The diagnosis of depressive disorders itself is not that simple in stroke patients, with several factors hindering the diagnosis (the lack of accurate screening tools, emotional and behavioral disturbances caused by infarct location in the brain, lack of evidently sufficient literature in stroke patients and stigmatic association in the society) [76].

\section{- Assessment tools (Rating scales)}

Among all the screening tools, Hamilton Depression Rating Scale (HDRS) has been found to be the most widely used [77]. Janneke, et al. used nine-item patient health questionnaire (PHQ9) and two-item patient health questionnaire (PHQ 2) [78]. They compared these two tools with International Diagnostic Interview, which assumed to have diagnostic reliability for depression. Later, several researchers found PHQ 9 and PHQ 2 as more precise but limited with the fact that they both need excellent verbal communication. Therefore, they recommended initially using PHQ 2 that focuses specifically on anhedonia and mood for every stroke patient. If PHQ 2 turns out positive, it is followed by PHQ 9. 


\begin{tabular}{|c|c|c|c|}
\hline Authors & $\begin{array}{l}\text { Number of } \\
\text { patients }\end{array}$ & Location of stroke & Relation to depression severity \\
\hline Pohjasvaara T, et al. 1998 [47] & 277 & Ischemic stroke- location not mentioned. & No statistical significance \\
\hline Hsieh LP, et al. 2005 [48] & 207 & $\begin{array}{l}\text { Ischemic stroke patients-location not } \\
\text { mentioned. }\end{array}$ & $\begin{array}{l}\text { No significant difference between the effect of location on } \\
\text { severity }\end{array}$ \\
\hline Spalletta G, et al. 2005 [49] & 200 & Not mentioned & Not mentioned \\
\hline Nys GM, et al. 2005 [50] & 126 & Not mentioned & $\begin{array}{l}\text { No association was found between severity of depressive } \\
\text { symptoms and lesion location }\end{array}$ \\
\hline Provinciali L, et al. 2008 [51] & 713 & $\begin{array}{l}\text { Ischemic stroke patients- location not } \\
\text { mentioned }\end{array}$ & $\begin{array}{l}\text { Only patients with total anterior cerebral ischemia (TACI) showed } \\
\text { a higher PSD occurrence } \\
\text { Left and right involvement were predictive of PSD }\end{array}$ \\
\hline Oladiji JO, et al. 2009 [52] & 51 & Location not mentioned & Stroke laterality was found to be a significant risk factor \\
\hline Nidhinandana S, et al. 2010 [53] & 101 & Location not mentioned & $\begin{array}{l}\text { There wasn't a statistical significance among depression and } \\
\text { non-depression groups }\end{array}$ \\
\hline Altieri M, et al. 2012 [54] & 105 & $\begin{array}{l}\text { Patients with minor ischemic; stroke - } \\
\text { location not mentioned }\end{array}$ & $\begin{array}{l}\text { No correlation was observed between lesion site or side and the } \\
\text { development of PSD }\end{array}$ \\
\hline Choi-Kwon S, et al. 2012 [55 & 508 & $\begin{array}{l}\text { Patients with acute ischemic; stroke- } \\
\text { location not mentioned. }\end{array}$ & $\begin{array}{l}\text { Lesion location is related to acute and subacute emotional } \\
\text { disturbances }\end{array}$ \\
\hline
\end{tabular}

\begin{tabular}{|c|c|c|c|}
\hline Authors & $\begin{array}{l}\text { Number of } \\
\text { patients }\end{array}$ & Location of stroke & Relation to depression severity \\
\hline Singh A, et al. 2000 [56] & 81 & Inferior frontal region & Predicts higher depression scores \\
\hline Desmond DW, et al. 2003 [57] & 421 & $\begin{array}{l}\text { Ischemic strokes in vascular areas that } \\
\text { supply limbic areas }\end{array}$ & Depression was associated with more severe stroke \\
\hline Tang WK, et al. 2005 [58] & 189 & Subcortical and ACA lesions & They were independent risk factors for PSD \\
\hline $\begin{array}{l}\text { Glodzik-Sobanska L, et al. } 2006 \\
\text { [59] }\end{array}$ & 26 & $\begin{array}{l}\text { Ischemic stroke located outside the frontal } \\
\text { lobes }\end{array}$ & $\begin{array}{l}31 \% \text { had depression at the first assessment } \\
35 \% \text { met the criteria of depression and follow up }\end{array}$ \\
\hline Caeiro L, et al. 2006 [60] & 178 & $\begin{array}{l}\text { Subarachnoid hemorrhage, Cerebral } \\
\text { hemorrhage and cerebral infarctions }\end{array}$ & Not mentioned \\
\hline Snaphaan L, et al. 2009 [53] & 420 & $\begin{array}{l}\text { Patients with an acute clinical } \\
\text { symptomatic transient ischemic attack or } \\
\text { cerebral infarction. }\end{array}$ & PSDS were not related to lesion side or location \\
\hline Zhang WN, et al. 2013 [61] & 102 & Acute ischemic stroke & The occurrence of PSD was unrelated with stroke location \\
\hline Shi YZ, et al. 2014 [62] & 1067 & Frontal lobe lesions & $\begin{array}{l}\text { Frontal lobe lesion was significantly associated with persistent/ } \\
\text { recurrent PSD }\end{array}$ \\
\hline Wu RH, et al. 2014 [63] & 65 & $\begin{array}{l}\text { Microbleeds left hemisphere and basal } \\
\text { ganglia }\end{array}$ & They are independent risk factors of late onset depression \\
\hline Wu RH, et al. 2014 [64] & 243 & Silent lacunar infarctions in basal ganglia & Associated with a higher risk of depression \\
\hline Terroni L, et al. 2015 [65] & 36 & Hippocampal/Para-hippocampal region & $\begin{array}{l}\text { Anhedonia in stroke patients is associated with the volume } \\
\text { of stroke lesion in the para-hippocampal gyrus and with } \\
\text { dysfunction of the hypothalamic-pituitary-adrenal axis }\end{array}$ \\
\hline Metoki N, et al. 2016 [66] & 421 & Frontal and temporal lobe infarctions. & $\begin{array}{l}\text { They are significant independent risk factors of early depressive } \\
\text { symptoms in the acute stage of stroke }\end{array}$ \\
\hline Wei C, et al. 2016 [67] & 368 & $\begin{array}{l}\text { Basal ganglia, corona radiate and internal } \\
\text { capsule }\end{array}$ & PSD was not related to lesion location \\
\hline
\end{tabular}

Various researchers used different kinds of assessment tools for their respective research studies. Beck Depression Inventory, Geriatric Depression Scale, and Montgomery-Asberg Depression Rating Scale are a few among them. A large trial was conducted in 2009 assessing three major levels. They used Beck Depression Inventory (BDI), Hamilton Depression Rating Scale and Clinical Global Impression assessment (CGI). Among them, BDI and HDRS were highly sensitive and specific respectively [79]. Berg, et al. also studied using Visual Analogue Mood Scale in patients with aphasia and cognitive impairment. However, it turned out not to be a reliable tool for depression [79].

Many screening assessment tools used for PSD are neither valid nor dependable because many exclude people with sensory loss, history of prior psychiatric illness and prior cognitive 
deficits which are not capable of accomplishing the screening tool. According to Hackett, et al. almost $50 \%$ of them is excluded in the projection as most stroke survivors develop cognitive deficits decreasing the efficacy and accuracy of them [76]. One can induce the deficits due to their infarct and might mislead as depression. It is a wise decision to use depression-rating scales to increase diagnostic accuracy, but the high scores in many stroke survivors are likely confounded with a neurological deficit from the attack [80].

The major limitation of using the assessment tools in the diagnosis of PSD was that many stroke survivors had sufficient communication capabilities. Aphasia in stroke survivors was in around $20 \%$ to $40 \%$ [81]. Therefore, screening tools were modified based on patient communicability, such as using visual analog scales or changing the questions or timing of the interviews, which ultimately decreased the accuracy of these tests.

The other limitation in the diagnosis of PSD is the inability to evaluate other comorbid psychiatric disorders co-existing with depression [13]. In addition to PSD, anxiety disorders are also commonly seen in stroke survivors. It is essential to diagnose anxiety, as it not only masks the diagnosis of depression but also impacts its outcome in stroke survivors. A few studies have evidenced around as high as $85 \%$ subjects developing co-morbid GAD and depression, three years following a stroke [82].

\section{- Health impacts and consequences}

Stroke might occur at any age, but is most commonly seen in elderly with 65 years and above. The functional disability associating with post-stroke depression might be a psychological response to physical incapacity. A recent study illustrated the effect of PSD on the quality of life expressed as impairments in activities of daily living (ADL). The study concluded that depressed stroke survivors had severe functional impairment in ADL at baseline and post rehabilitation, compared to non-depressed survivors. Based on these studies, functional disability is shown to be more prevalent in PSD patients [83].

Zikic, et al. study showed the association of PSD to social withdrawal and social deterioration. There is also a significant correlation between cognitive and functional disabilities and social functioning in PSD patients. Limitations in physical and intellectual abilities result in social withdrawal as well as social discontentment in relationships. They also reported that three years following a stroke, only $7 \%$ of depressed patients and $66 \%$ of non-depressed patients were seen to socialize with their friends and relatives [83].

Moreover, studies reported that stroke survivors' psychological symptoms have negative impacts on family caregivers, causing emotional distress. Some stroke survivors are diagnosed with dementia and are under the care of the household. Once discharged from inpatient care their caregivers experience both physical and emotional distress [84].

\section{- Prevention of post-stroke depression}

Post-stroke depression (PSD) causes high morbidity and mortality. Therefore, PSD shows potential candidacy for primary prevention [85]. There are three levels of intervention: global (for the whole stroke population), selective (for stroke patients with high risk), and targeted (for the stroke patients with early signs or symptoms of the disease). Primary intervention for PSD is selective [86].

Primary intervention may include psychological or pharmacological approaches. Both can be effective. Psychological intervention is a stepped care approach. The first step is to carefully watch the patient for 6-8 weeks as some patients with early symptoms may recover spontaneously. When patients continue to have depressive symptoms, they are taught a self-helping approach. The third step is a shortterm psychological intervention as cognitive behavioural therapy or problem-solving therapy. The last step is specialized health care [85].

The other approach is pharmacological intervention. It is based on counteracting the pathophysiology of stroke. Stroke may decrease levels of monoamines and increase production of hydrocortisone, serotonin, and inflammatory cytokines (IL-1 \& TNF) [87]. Antidepressants can induce neurogenesis [88], reverse the proinflammatory pathway and prevent depression [89].

However, there is a controversy regarding the effect of antidepressants in the prevention of depression after stroke. Zhang, et al. showed that duloxetine could reduce major and minor depression by $16 \%$ but they followed up patients for only 12 weeks [90]. Supporting equivalent results, Rasmussen, et al. found that sertraline decreased depression by $18 \%$ after a one year follow-up [91]. Robinson, et al. investigated 
the effect of escitalopram in post-stroke patients and found that escitalopram could decrease the prevalence of depression by only $13.9 \%$ [92].

Some studies revealed that brief treatment with antidepressants may have a beneficial effect on the long-term morbidity and mortality of stroke [93]. Almeida, et al. examined the effect of sertraline $50 \mathrm{mg} /$ day for 24 weeks. The results showed no significant difference between the effect of sertraline and placebo, plus routine medications [94]. In addition, antidepressants have side effects and should be used carefully. For example, fluoxetine inhibits P450 enzyme and interacts with cardiac medications [95]. Nortriptyline also interacts with cardiac medications and may cause delirium [96].

A Cochrane review by Fullerton, et al. found that antidepressants did not show any evidence to prevent post-stroke depression [96]. However, psychotherapy significantly prevented depression and improved mood. Another study showed that antidepressants may decrease the prevalence of depression in stroke patients [97]. Further research is needed to find out the role of antidepressants in PSD prevention.

\section{- Assessing suicidality}

Post-stroke depression aggravates other preexisting medical conditions like cardiovascular illness, hypertension, hypercholesterolemia, diabetes and COPD, and can ultimately lead to death by suicide [22]. It is paramount to assess suicidality in each patient at every appointment because it decreases motivation, then further resulting in the lack of response or compliance to their treatment causing self-destruction [98]. Therefore, continued monitoring of the treatment response is essential with reassurance.

Suicidality in stroke patients is highly prevalent among young adults, with risk being significantly higher in the first five years after a stroke. Jorge, et al. found that patients with PSD are 3.5 times more likely to die ten years after the occurrence of a stroke [99]. While the major proportion of stroke patients died due to their physical disabilities or other medical conditions, suicide does play a significant role. Also, it is evident that suicidal ideation is common with physically challenged patients, patients living alone, and the ones with depressive symptoms. They also noted the differences in the etiologies of suicidal plans among these patients, indicating that acute onset plans go hand in hand with alcohol abuse and younger age, whereas delayed onset suicidal plans were shown to relate with posterior lesions and greater physical disabilities resulting from the stroke. Furthermore, impulsivity and suicide risks were found to be more prevalent in stroke, resulting in frontal lobe impairment. According to the study mentioned above, four out of the six patients they evaluated with suicidal ideation experienced depression and ultimately died by suicide in six months following a stroke. Therefore, emphasis upon depression and suicide assessment during stroke rehabilitation periods in post-stroke patients is important.

Finally, the risk of mortality increases significantly when neuropsychiatric disorders co-exist with other medical conditions. Research has highlighted the association between heart disorders such as myocardial infarction and PSD, showing that depression can cause disruption of immune and coagulation mechanisms, resulting in increased risk of cardiovascular disease and mortality [100]. Studies are showing the association of PSD with the decreased heart rate variability, and this disturbance of the autonomic nervous system might be a contributing factor to cardiovascular mortality in these patients [101].

\section{Treatment}

Depression reduces the extent of people receiving treatment, impedes rehabilitation and their ability to socialize and rejuvenate past life. The early identification and proper treatment are of paramount importance for decreasing morbidity and disability associated with it. Given the difference in population dynamics of the stroke patients, there are some questions on the recommended treatment protocols that need review.

In PSD, antidepressant therapy is considered to be the first treatment choice than any other treatment modality. However, the reasons for treatment failures include the timing of intervention or the side effects from medications. It is vital to remain cautious about the systemic side effects, especially in the cardiovascular system, fear of drug interactions with multiple comorbidities, and poor response to antidepressants in elderly which cause dropouts in treatment [102]. However, several factors play a role in stroke patients to receive treatment for depression - the presence of other comorbid medical conditions, financial burden and stigma associated with mental illness [103]. According to them, only less than $2 \%$ stroke survivors persist depressive symptoms after treating with antidepressants. 


\section{Pharmacotherapy in PSD}

Selective Serotonin Reuptake Inhibitors and TriCyclic Antidepressants are the most widely used pharmacological intervention for PSD [104]. They both inhibit production of inflammatory cytokines by microglial cells, leading to neurogenesis and neuroplasticity that help in physical recovery and cognitive improvement after stroke. Additionally, there is a treatment synergy observed between motor development and reduced incidence of depression with early use of SSRIs following a stroke. Thus, this possible role of SSRI therapy in motor recovery may lead to immediate rehabilitation [27].

\section{SSRIS}

These are the preferred choice of the available range of antidepressants due to their least cholinergic and cardiovascular side effects. Apart from the variable side effects profile of SSRIs, the risk of platelet and cytochrome P450 inhibition demands vigilant monitoring to avoid intracranial bleeds leading to haemorrhagic stroke, lethal drug interactions and the toxicities ultimately causing treatment dropout [105].

Among the SSRI group, citalopram, fluoxetine, and sertraline are widely in use. However, these drugs vary in the pharmacokinetics that makes them not generalized to all patients. The efficacy of these drugs depends on the timing of the intervention. The earlier the intervention, the better will be the outcome [104]. Sertraline showed improved emotionalism and hostility. Fluoxetine shared similar results in addition to control of excessive, inappropriate laughter and excessive crying spells in the patient [104]. A three months' combination treatment with fluoxetine and nortriptyline in stroke survivors of more than one year demonstrated marked response after adjusting significant confounding factors. The confounding factors include age, rehabilitation hours, baseline stroke severity and baseline HDRS.

\section{Other Agents}

TCAs have also been proven to be effective but are not recommendable as the first line treatment due to its affinity for various receptors, including histaminergic, alpha one adrenergic and muscarinic acetyl-cholinergic receptors. A particular caution is required while prescribing TCAs to the elderly population, as they likely have an underlying cardiac etiology and an arrhythmogenic effect that may prove lethal [106].

Using the stimulant medications, like methylphenidate (MPH) in elderly population for major depression, has shown itself to be beneficial in the rehabilitation of acute stroke patients. The antidepressants also include noradrenaline reuptake inhibitors like reboxetine, used in retarded depression [107]. Retarded depression is a clinical state where the patient is lethargic and restless without the anxiety component. It is important to reinitiate the antidepressants in patients who were taking them before the stroke [104].

Moreover, still, some debate exists regarding the treatment with antidepressants and achieving complete remission [108]. According to a comprehensive review published in 2008 , if we compare pre and post treatment results, there are some evident improvements, but to reach complete premorbid condition is an uphill task keeping in mind various somatic and systemic presentations of symptoms in stroke survivors [109].

\section{Other Treatment Modalities}

In non-pharmacological treatment modalities, none has been found to be more effective than pharmacological therapies, and there is a limitation of use in cases where the use of antidepressants defines some restrictions [109]. Cognitive Behavioral Therapy (CBT) has some role if personalized, and there is the utilization of augmented approach in a case to case basis, but more research options are considered to come up with a further outcome [110]. To see more desirable results, pharmacotherapy and psychotherapy should both be useful, rather than pharmacotherapy to act alone. They are already proven to be more effective in combination than using alone when used for depressive disorders without stroke [22]. However, we need more literature studies demonstrating their efficacy in the setting of stroke.

Trans Magnetic Stimulation (TMS) is also an alternative option, which is a non-expensive, non-invasive and relatively painless treatment. The repetitive TMS (rTMS) is used to decrease the inter-hemispheric differences in cortical excitability. It has proven to be effective in refractory depression in stroke patients [111]. Murray, et al. studied the use of Electro 
Convulsive Therapy (ECT) in 193 PSD patients and they demonstrated ECT as an efficacious and safer modality [112]. However, we need more evidence-based data for a wider use of ECT and TMS in the setting of stroke. Also, it requires proper caution and ruling out of cardiovascular illness before using ECT [113134] (Table 6).

\section{Treatment Studies of Post Stroke Depression}

\section{- Recovery/Prognosis}

Though there was a rectification of mood components, there were no studies concluding restoration of serotonergic dysfunction as the only attributor for PSD recovery [104]. Murray, et al. study showed only clinical significance with sertraline with no statistical significance [135]. There was no statistical significance seen with reboxetine either [107]. The limitations are being unable to see any significant difference in activities of daily living (ADL) and amended disability. The majority cases are underdiagnosed as the disability may be due to stroke or depression, and as a result, the treatment was not initiated on time. The other alternatives to antidepressants include short duration atypical antipsychotics, mood stabilizers, and psychostimulants for apathy and fatigue.

Kim, et al. found out that a polymorphism of serotonin $2 \mathrm{a}$ serotonergic genes relates to suicidal ideation two weeks after stroke [136]. Hence, SSRI needs to undergo careful monitoring as they contribute to suicidal ideation. According to a study antidepressants protect against acute ischemic neuronal injury, increases ischemia-induced neurogenesis and brain repair that influence stroke outcomes [137].

Prevention can be a valuable strategy and a way to achieve positive results if risk factors like hypertension, diabetes, cigarette smoking, and hyperlipidemia are under control. However, antidepressant therapy has proved effective to some extent in controlling the incidence of depression after stroke but has a limited role in controlling the severity of symptoms $[85,138]$. At the present scenario, there is a need for more research trying a different combination of antidepressants with strict monitoring and follow up to keep a check on the side effect profile and prevent dropouts to maintain optimal treatment efficacy [139].

\section{Conclusion}

Post-Stroke Depression has negative impacts on functional recovery, cognition, and the rehabilitation of stroke patients. It certainly increases their risk for morbidity and mortality. Henceforth, it is essential to diagnose and treat PSD appropriately. Post-stroke depression appears not purely by biological or psychological means, but instead is multi-factorial in origin. Therefore, it is vital that all factors are accountable for assessment.

As evidenced, none of the assessment tools can be universally acceptable to evaluate poststroke depression. Moreover, each patient should undergo a specific individual assessment considering their history in addition to the generic assessment. Further extensive research and larger prospective studies are required in the future to understand and design a more accurate assessment for early and precise diagnosis of PSD. However, it is also essential that all physicians get enough training to be able to evaluate and assess stroke patients clinically for PSD. Primary care doctors must be vigilant enough to assess PSD based on clinical evaluation and transfer these patients to the appropriate care, if needed.

So far, studies have not concluded any definitive therapeutic choice for PSD, even though clinical depression antidepressants, especially SSRIs, are proven to have some positive outcome for PSD. Unfortunately, none of the antidepressants have shown to be effectively beneficial to improve the prognosis significantly. Future studies should be focused on understanding whether different combinations of antidepressants can help treat PSD. In addition to pharmacotherapy, it is crucial that these patients receive cognitive behavioral therapy and group counseling to improve the overall outcome. It is also important that physical disabilities of these patients should be put into consideration and getting them aggressively involved in physical therapy for conditions like spasticity and aphasia might help to alleviate the depression to some extent. In conclusion, it is essential to understand whether the amalgam of pharmacotherapy with other psychotherapies can effectively treat PSD. Therefore, further research is a must. 


\begin{tabular}{|c|c|c|c|c|}
\hline Study & Study Design & $\begin{array}{l}\text { Number } \\
\text { of } \\
\text { Patients }\end{array}$ & Treatment Strategy & Results/ Treatment Response \\
\hline $\begin{array}{l}\text { Lipsey JR, et al. } 1984 \\
\text { [114] }\end{array}$ & A double blind trial & 34 & $\begin{array}{l}\text { Tricyclic antidepressant } \\
\text { Nortriptyline }\end{array}$ & $\begin{array}{l}\text { Successfully treated patients who had serum nortriptyline } \\
\text { levels in the therapeutic range }\end{array}$ \\
\hline $\begin{array}{l}\text { Reding MJ, et al. } \\
1986[115]\end{array}$ & A double blind trial & 27 & $\begin{array}{l}\text { Antidepressant trazodone } \\
\text { hydrochloride (Desyrel) } 200 \\
\mathrm{mg} / \mathrm{d}\end{array}$ & $\begin{array}{l}\text { An abnormal dexamethasone suppression test result was } \\
\text { associated with a significant improvement in the Barthel } \\
\text { ADL scores of patients receiving trazodone }\end{array}$ \\
\hline $\begin{array}{l}\text { Andersen G, et al. } \\
1994 \text { [116] }\end{array}$ & $\begin{array}{l}\text { A double-blind, placebo- } \\
\text { controlled trial }\end{array}$ & 66 & $\begin{array}{l}\text { Selective serotonin } \\
\text { reuptake inhibitor } \\
\text { citalopram ( } 10 \text { to } 40 \mathrm{mg} / \mathrm{d})\end{array}$ & $\begin{array}{l}\text { Citalopram offers an advantageous new treatment of } \\
\text { post-stroke depression that is both safe and effective }\end{array}$ \\
\hline $\begin{array}{l}\text { Grade C, et al. } 1998 \\
\text { [117] }\end{array}$ & $\begin{array}{l}\text { A prospective, } \\
\text { randomized, double-blind, } \\
\text { placebo-controlled study }\end{array}$ & 21 & $\begin{array}{l}\text { CNS stimulant } \\
\text { Methylphenidate }\end{array}$ & $\begin{array}{l}\text { Methylphenidate is a safe and effective intervention in } \\
\text { early post-stroke rehabilitation }\end{array}$ \\
\hline $\begin{array}{l}\text { Robinson RG, et al. } \\
2000 \text { [118] }\end{array}$ & $\begin{array}{l}\text { A Placebo-Controlled, } \\
\text { Double-Blind Study }\end{array}$ & 104 & $\begin{array}{l}\text { SSRI Nortriptyline or } \\
\text { fluoxetine }\end{array}$ & $\begin{array}{l}\text { Nortriptyline produced a significantly higher response } \\
\text { rate than fluoxetine or placebo in treating post-stroke } \\
\text { depression, in improving anxiety symptoms, and in } \\
\text { improving recovery of activities of daily living }\end{array}$ \\
\hline $\begin{array}{l}\text { Wiart L, et al. } 2000 \\
{[119]}\end{array}$ & $\begin{array}{l}\text { A double-blind placebo- } \\
\text { controlled study }\end{array}$ & 31 & SSRI fluoxetine & $\begin{array}{l}\text { Patients treated with fluoxetine showed a significant } \\
\text { improvement and a higher response rate }\end{array}$ \\
\hline $\begin{array}{l}\text { Fruehwald S, et al. } \\
2003[120]\end{array}$ & $\begin{array}{l}\text { A double-blind placebo } \\
\text { controlled study with an } \\
\text { open-label long-term } \\
\text { follow up }\end{array}$ & 54 & SSRI fluoxetine & $\begin{array}{l}\text { The effect of fluoxetine was obvious at the follow-up. } \\
\text { Fluoxetine treatment was well tolerated and safe }\end{array}$ \\
\hline $\begin{array}{l}\text { Rampello L, et al. } \\
2005 \text { [107] }\end{array}$ & $\begin{array}{l}\text { A random, placebo- } \\
\text { controlled study }\end{array}$ & 31 & $\begin{array}{l}\text { A noradrenaline reuptake } \\
\text { inhibitor, Reboxetine ( } 4 \mathrm{mg} \text {, } \\
\text { twice daily, for } 16 \text { weeks) }\end{array}$ & $\begin{array}{l}\text { Reboxetine showed a good efficacy, safety and tolerability } \\
\text { in PSD patients affected by "retarded" depression }\end{array}$ \\
\hline $\begin{array}{l}\text { Choi-Kwon S, et al. } \\
2006 \text { [121] }\end{array}$ & $\begin{array}{l}\text { A double-blind, placebo- } \\
\text { controlled study }\end{array}$ & 152 & SSRI fluoxetine $20 \mathrm{mg} /$ day & $\begin{array}{l}\text { Fluoxetine significantly improved PSEl and PSAP, whereas } \\
\text { no definitive improvement of PSD was found }\end{array}$ \\
\hline $\begin{array}{l}\text { Kucukalić A, et al. } \\
2007[122]\end{array}$ & $\begin{array}{l}\text { A prospective single arm } \\
\text { study }\end{array}$ & 30 & Venlafaxine for 3 months & $\begin{array}{l}\text { The results indicate a statistically significant reduction } \\
\text { of depressive symptoms following three months of } \\
\text { treatment with venlafaxine }\end{array}$ \\
\hline $\begin{array}{l}\text { Li LT, et al. } 2008 \\
{[123]}\end{array}$ & $\begin{array}{l}\text { A randomized, } 3 \text { armed, } \\
\text { placebo controlled trial }\end{array}$ & 150 & $\begin{array}{l}\text { Free and Easy Wanderer } \\
\text { Plus or fluoxetine or } \\
\text { placebo }\end{array}$ & $\begin{array}{l}\text { Significantly higher clinical response rates were observed } \\
\text { in both the FEWP and fluoxetine groups compared to the } \\
\text { placebo group. There was no difference in the response } \\
\text { rates between the FEWP group and the fluoxetine group }\end{array}$ \\
\hline $\begin{array}{l}\text { Cravello L, et al. } \\
2009[124]\end{array}$ & $\begin{array}{l}\text { A randomized open-label } \\
\text { study }\end{array}$ & 50 & $\begin{array}{l}\text { The SNRI venlafaxine SR } \\
\text { ( } 75-150 \mathrm{mg} / \text { die) or the SSRI } \\
\text { fluoxetine ( } 20-40 \mathrm{mg} / \mathrm{die})\end{array}$ & $\begin{array}{l}\text { The two groups showed similar improvement but } \\
\text { venlafaxine had a greater improvement on alexithymia } \\
\text { severity }\end{array}$ \\
\hline $\begin{array}{l}\text { Mikami K, et al. } 2011 \\
\text { [125] }\end{array}$ & $\begin{array}{l}\text { A double-blind } \\
\text { randomized study }\end{array}$ & 83 & $\begin{array}{l}\text { Fluoxetine, nortriptyline or } \\
\text { placebo }\end{array}$ & $\begin{array}{l}\text { Patients treated with antidepressants had better recovery } \\
\text { from disability by } 1 \text {-year post-stroke }\end{array}$ \\
\hline $\begin{array}{l}\text { Hackett ML, et al. } \\
2012[126]\end{array}$ & $\begin{array}{l}\text { A randomized controlled } \\
\text { trial }\end{array}$ & 201 & $\begin{array}{l}\text { A postcard was sent } \\
\text { monthly to participants } \\
\text { compared with usual care }\end{array}$ & No significant difference between both groups \\
\hline $\begin{array}{l}\text { Sunami E, et al. } 2012 \\
{[127]}\end{array}$ & $\begin{array}{l}\text { A prospective controlled } \\
\text { trial }\end{array}$ & 19 & Fluvoxamine or placebo & $\begin{array}{l}\text { Fluvoxamine alleviated both the depressive state and } \\
\text { sleep disturbances }\end{array}$ \\
\hline $\begin{array}{l}\text { Huang H, et al. } 2012 \\
{[128]}\end{array}$ & $\begin{array}{l}\text { A prospective, controlled } \\
\text { study }\end{array}$ & 182 & $\begin{array}{l}\text { Carotid stent angioplasty or } \\
\text { antidepressants (SSRI) }\end{array}$ & CAS relieves PSD symptoms. Effect was higher than SSRI \\
\hline $\begin{array}{l}\text { Zhang LS, et al. } 2013 \\
{[90]}\end{array}$ & An open single-blind trial & $\begin{array}{l}95 \\
\text { ischemic } \\
\text { stroke } \\
\text { patients } \\
\text { without } \\
\text { depression }\end{array}$ & $\begin{array}{l}\text { Duloxetine (dose range } \\
30-90 \mathrm{mg} \text { ) for } 12 \text { weeks in } \\
\text { addition to routine therapy } \\
\text { or routine ischemic stroke } \\
\text { therapy }\end{array}$ & $\begin{array}{l}\text { Duloxetine spared ischemic stroke patients from both } \\
\text { minor and major depression by } 16 \%\end{array}$ \\
\hline $\begin{array}{l}\text { Man SC, et al. } 2014 \\
{[129]}\end{array}$ & $\begin{array}{l}\text { A single-blind, } \\
\text { randomized controlled } \\
\text { trial }\end{array}$ & 43 & $\begin{array}{l}12 \text { sessions of DCEAS, } \\
\text { plus SSRI, plus body } \\
\text { electroacupuncture }(n= \\
23) \text {, or sham (non-invasive } \\
\text { cranial electroacupuncture, } \\
n-C E A) \text {, plus SSRI, plus body } \\
\text { electroacupuncture }(n=20)\end{array}$ & $\begin{array}{l}\text { A combination of DCEAS and body acupuncture can be } \\
\text { considered a treatment option for neuropsychiatric } \\
\text { sequelae of a stroke }\end{array}$ \\
\hline
\end{tabular}




\begin{tabular}{|c|c|c|c|c|}
\hline $\begin{array}{l}\text { Yaozhi HU, et al. } \\
2015 \text { [130] }\end{array}$ & $\begin{array}{l}\text { A randomized controlled } \\
\text { study }\end{array}$ & 118 & $\begin{array}{l}\text { Antidepressant } \\
\text { Pioglitazone ( } 30 \mathrm{mg} \text { once } \\
\text { daily) }\end{array}$ & $\begin{array}{l}\text { Pioglitazone effectively decreased HAMD scores and FINS } \\
\text { values in patients with PSD }\end{array}$ \\
\hline $\begin{array}{l}\text { Kootker JA, et al. } \\
2015[131]\end{array}$ & $\begin{array}{l}\text { A description of a } \\
\text { treatment protocol }\end{array}$ & & $\begin{array}{l}\text { The intervention consisted } \\
\text { of } 12 \text { one-hour sessions } \\
\text { with a psychologist } \\
\text { and three or four one- } \\
\text { hour sessions with an } \\
\text { occupational or movement } \\
\text { therapist }\end{array}$ & \\
\hline $\begin{array}{l}\text { Yan D, et al. } 2015 \\
{[132]}\end{array}$ & $\begin{array}{l}\text { A three-arm randomized } \\
\text { control trial }\end{array}$ & 90 & $\begin{array}{l}\text { Fluoxetine group ( } 20 \mathrm{mg} \text { / } \\
\text { day), Hyperbaric oxygen } \\
\text { therapy group (once a day, } \\
5 \text { days/week), or both }\end{array}$ & $\begin{array}{l}\text { The total effective rate of combined hyperbaric oxygen } \\
\text { therapy group after the treatment was higher than the } \\
\text { other two groups }\end{array}$ \\
\hline $\begin{array}{l}\text { van Eeden M, et al. } \\
2015 \text { [133] }\end{array}$ & $\begin{array}{l}\text { A trial-based economic } \\
\text { evaluation }\end{array}$ & 61 & $\begin{array}{l}\text { A cognitive behavioral } \\
\text { therapy augmented } \\
\text { with occupational and } \\
\text { movement therapy or } \\
\text { computerized cognitive } \\
\text { training program } \\
\text { (CogniPlus) }\end{array}$ & $\begin{array}{l}\text { The stroke-specific augmented CBT intervention did } \\
\text { not show convincing cost-effectiveness results. There } \\
\text { is potential cost-effectiveness of an adjusted cognitive } \\
\text { behavioral therapy intervention }\end{array}$ \\
\hline $\begin{array}{l}\text { Valiengo L, et al. } \\
2017 \text { [134] }\end{array}$ & $\begin{array}{l}\text { A randomized, sham- } \\
\text { controlled, double- } \\
\text { blinded trial }\end{array}$ & 48 & $\begin{array}{l}12-30 \text { min sessions of } 2 \mathrm{~mA} \\
\text { anodal left/cathodal right } \\
\text { dorsolateral prefrontal } \\
\text { Tdcs were administered } \\
\text { over } 6 \text { weeks (once daily on } \\
\text { weekdays for } 2 \text { weeks, then } \\
1 \text { session every other week) }\end{array}$ & $\begin{array}{l}\text { Active tDCS was significantly superior to sham at the end } \\
\text { point }\end{array}$ \\
\hline
\end{tabular}

\section{References}

1. Burvill PW, Johnson GA, Jamrozik KD, et al. Prevalence of depression after stroke: the Perth Community Stroke Study. Br. J. Psychiatry 166(3), 320-327 (1995).

2. Gaete JM, Bogousslavsky J. Post-stroke depression. Expert. Rev. Neurother 8(1), 75-92 (2008).

3. American Psychiatric Association. Diagnostic and statistical manual of mental disorders (DSM-5 ${ }^{\circledR}$ ): American Psychiatric Pub (2013).

4. Folstein MF, Maiberger R, McHugh PR. Mood disorder as a specific complication of stroke. J. Neurol. Neurosurg. Psychiatry 40(10), 10181020 (1977).

5. Beblo T, Wallesch CW, Herrmann M. The crucial role of frontostriatal circuits for depressive disorders in the postacute stage after stroke. Neuropsychiatry. Neuropsychol. Behav. Neurol 12(4), 236-246 (1999).

6. Starkstein S, Bryer J, Berthier M, et al. Depression after stroke: the importance of cerebral hemisphere asymmetries. J. Neuropsychiatry. Clin. Neurosci 3(3), 276-285 (1991).

7. Gainotti G, Azzoni A, Marra C. Frequency, phenomenology and anatomical-clinical correlates of major post-stroke depression. $\mathrm{Br}$. J. Psychiatry175(2), 163-167 (1999).

8. House A. Depression associated with stroke. J. Neuropsychiatry. Clin. Neurosci 8(4), 453-457 (1996).
9. Robinson RG, Starr LB, Kubos KL, et al. A two-year longitudinal study of post-stroke mood disorders: findings during the initial evaluation. Stroke 14(5), 736-741 (1983).

10. Robinson RG, Kubos KL, Starr LB, et al. Mood disorders in stroke patients: importance of location of lesion. Brain 107(1), 81-93 (1984).

11. Starkstein SE, Robinson RG, Price TR. Comparison of cortical and subcortical lesions in the production of poststroke mood disorders. Brain 110(4), 1045-1059 (1987).

12. Mozaffarian D, Benjamin EJ, Go AS, et al. Heart Disease and Stroke Statistics-2015 Update: A Report From the American Heart Association. Circulation 131(4), e29-e322 (2015).

13. Whyte EM, Mulsant BH. Post stroke depression: epidemiology, pathophysiology, and biological treatment. Biol. Psychiatry 52(3), 253-264 (2002).

14. Lökk J, Delbari A. Management of depression in elderly stroke patients. Neuropsychiatr. Dis. Treat 6(1), 539-549 (2010).

15. Robinson RG, Starr LB, Price TR. A two year longitudinal study of mood disorders following stroke. Prevalence and duration at six months follow-up. Br. J. Psychiatry 144(3), 256-262 (1984).

16. Hackett ML, Yapa C, Parag V, et al. Frequency of depression after stroke: a systematic review of observational studies. Stroke 36(6), 13301340 (2005).

17. Hackett ML, Pickles K. Part I: frequency of depression after stroke: an updated systematic review and meta-analysis of observational studies. Int. J. Stroke 9(8), 10171025 (2014).

18. Sturm JW, Donnan GA, Dewey HM, et al. Quality of life after stroke: the North East Melbourne Stroke Incidence Study (NEMESIS). Stroke 35(10), 2340-2345 (2004).

19. Schubert DS, Taylor C, Lee $S$, et al. Detection of depression in the stroke patient. Psychosomatics 33(3), 290-294 (1992).

20. Robinson RG. Poststroke depression: prevalence, diagnosis, treatment, and disease progression. Biol. Psychiatry 54(3), 376-87 (2003).

21. Aben I, Verhey F, Honig A, et al. Research into the specificity of depression after stroke: a review on an unresolved issue. Prog. Neuropsychopharmacol. Biol. Psychiatry 25(4), 671-689 (2001).

22. Gelenberg AJ, Hopkins HS. Assessing and treating depression in primary care medicine. Am. J. Med 120(2), 105-108 (2007).

23. Starkstein SE, Berthier ML, Fedoroff $P$, et al. Anosognosia and major depression in 2 patients with cerebrovascular lesions. Neurology 40(9), 1380-1382 (1990).

24. Starkstein SE, Fedoroff JP, Price TR, et al. Anosognosia in patients with cerebrovascular lesions. A study of causative factors. Stroke 23(10), 1446-1453 (1992).

25. Sachdev PS, Chen X, Joscelyne A, et al. Amygdala in stroke/transient ischemic attack patients and its relationship to cognitive 
impairment and psychopathology: the Sydney Stroke Study. Am. J. Geriatr. Psychiatry 15(6), 487-496 (2007).

26. de Groot JC, de Leeuw F-E, Oudkerk M, et al. Cerebral white matter lesions and depressive symptoms in elderly adults. Arch. Gen. Psychiatry 57(11), 1071-1076 (2000).

27. Flaster M, Sharma A, Rao M. Poststroke depression: a review emphasizing the role of prophylactic treatment and synergy with treatment for motor recovery. Top. Stroke. Rehabil 20(2), 139-150 (2013).

28. Sharpe M, Hawton K, House A, et al. Mood disorders in long-term survivors of stroke: associations with brain lesion location and volume. Psychol. Med 20(04), 815-828 (1990).

29. Andersen G, Vestergaard K, IngemannNielsen $M$, et al. Risk factors for post-stroke depression. Acta. Psychiatr. Scand (3), 193198 (1995).

30. Herrmann M, Bartels C, Schumacher M, et al. Poststroke depression. Stroke 26(5), 850856 (1995).

31. lacoboni M, Padovani A, Di Piero V, et al. Post-stroke depression: relationships with morphological damage and cognition over time. Ital. J. Neurol. Sci 16(3), 209-216 (1995).

32. Bendsen BB, Bendsen EB, Lauritzen L, et al. Post-stroke patients in rehabilitation. The relationship between biological impairment (CT scanning), physical disability and clinical depression. Eur. Psychiatry 12(8), 399-404 (1997).

33. Paolucci S, Antonucci G, Pratesi L, et al. Poststroke depression and its role in rehabilitation of inpatients. Arch. Phys. Med. Rehabil 80(9), 985-990 (1999).

34. Shimoda K, Robinson RG. The relationship between poststroke depression and lesion location in long-term follow-up. Biol. Psychiatry 45(2), 187-192 (1999).

35. Fuentes B, Ortiz X, Sanjose B, et al. Poststroke depression: can we predict its development from the acute stroke phase? Acta. Neurol. Scand 120(3), 150-156 (2009).

36. Jiang $X$, Lin Y, Li Y. Correlative study on risk factors of depression among acute stroke patients. Eur. Rev. Med. Pharmacol. Sci 18(9), 1315-1323 (2014).

37. Starkstein $\mathrm{SE}$, Fedoroff $\mathrm{P}$, Berthier ML, et al. Manic-depressive and pure manic states after brain lesions. Biol. Psychiatry 29(2), 149-158 (1991).

38. Aström M, Adolfsson R, Asplund K. Major depression in stroke patients. A 3-year longitudinal study. Stroke 24(7), 976-982 (1993).

39. González-Torrecillas JL, Mendlewicz J, Lobo A. Effects of early treatment of poststroke depression on neuropsychological rehabilitation. Int. Psychogeriatr 7(04), 547560 (1995).

40. Kase C, Wolf $\mathrm{P}$, Kelly-Hayes $\mathrm{M}$, et al. Intellectual decline after stroke. Stroke 29(4), 805-812 (1998).

41. Berg A, Palomäki H, Lehtihalmes $\mathrm{M}$, et al. Poststroke depression in acute phase after stroke. Cerebrovasc. Dis 12(1), 14-20 (2001).

42. Nishiyama Y, Komaba Y, Ueda M, et al. Early depressive symptoms after ischemic stroke are associated with a left lenticulocapsular area lesion. J. Stroke. Cerebrovasc. Dis 19(3), 184-189 (2010).

43. Rajashekaran P, Pai K, Thunga R, et al. Poststroke depression and lesion location: A hospital based cross-sectional study. Indian. J. Psychiatry 55(4), 343-348 (2013).

44. Alajbegovic A, Djelilovic-Vranic J, Alajbegovic $S$, et al. Post stroke depression. Med. Arch 68(1), 47 (2014).

45. MacHale SM, O'Rourke SJ, Wardlaw JM, et al. Depression and its relation to lesion location after stroke. J. Neurol. Neurosurg. Psychiatry 64(3), 371-374 (1998)

46. Mutai $H$, Furukawa $T$, Houri A, et al. Factors associated with multidimensional aspect of post-stroke fatigue in acute stroke period. Asian. J. Psychiatr 26(1), 1-5 (2017).

47. Pohjasvaara T, Leppävuori A, Siira I, et al. Frequency and clinical determinants of poststroke depression. Stroke 29(11), 23112317 (1998)

48. Hackett ML, Yapa C, Parag V, et al. Frequency of depression after stroke. Stroke 36(6), 1330-1340 (2005).

49. Spalletta G, Ripa A, Caltagirone C. Symptom profile of DSM-IV major and minor depressive disorders in first-ever stroke patients. Am. J. Geriatr. Psychiatry 13(2), 108115 (2005).

50. Nys G, Van Zandvoort M, Van der Worp H, et al. Early depressive symptoms after stroke: neuropsychological correlates and lesion characteristics. J. Neurol. Sci 228(1), 27-33 (2005).

51. Provinciali L, Paolucci S, Torta R, et al. Depression after first-ever ischemic stroke: the prognostic role of neuroanatomic subtypes in clinical practice. Cerebrovasc. Dis 26(6), 592-599 (2008).

52. Oladiji J, Akinbo S, Aina O, et al. Risk factors of post-stroke depression among stroke survivors in Lagos, Nigeria: original article. Afr. J. Psychiatry 12(1), 47-51 (2009).

53. Snaphaan L, Van Der Werf S, Kanselaar K, et al. Post-stroke depressive symptoms are associated with post-stroke characteristics. Cerebrovasc. Dis 28(6), 551-557 (2009).

54. Altieri M, Maestrini I, Mercurio A, et al.
Depression after minor stroke: prevalence and predictors. Eur. J. Neurol 19(3), 517-521 (2012).

55. Choi-Kwon S, Han K, Choi S, et al. Poststroke depression and emotional incontinence Factors related to acute and subacute stages. Neurology 78(15), 1130-1137 (2012).

56. Singh A, Black SE, Herrmann N, et al. Functional and neuroanatomic correlations in poststroke depression. Stroke 31(3), 637644 (2000)

57. Desmond DW, Remien RH, Moroney JT, et al. Ischemic stroke and depression. J. Int Neuropsychol. Soc 9(3), 429-439 (2003).

58. Tang WK, Chan SS, Chiu HF, et al. Poststroke depression in Chinese patients: frequency, psychosocial, clinical, and radiological determinants. J. Geriatr. Psychiatry. Neurol 18(1), 45-51 (2005)

59. Glodzik-Sobanska L, Slowik A, McHugh P, et al. Single voxel proton magnetic resonance spectroscopy in post-stroke depression. Psychiatry. Res 148(2-3), 111-120 (2006).

60. Caeiro L, Ferro JM, Santos CO, et al. Depression in acute stroke. J. Psychiatry. Neurosci 31(6), 377-383 (2006).

61. Zhang WN, Pan $\mathrm{YH}$, Wang $X Y$, et al. A prospective study of the incidence and correlated factors of post-stroke depression in China. PLoS. One 8(11), e78981 (2013).

62. Shi YZ, Xiang YT, Wu SL, et al. The relationship between frontal lobe lesions, course of post-stroke depression, and 1 -year prognosis in patients with first-ever ischemic stroke. PLoS. One 9(7), e100456 (2014)

63. Wu RH, Feng C, Xu Y, et al. Late-onset depression in the absence of stroke: associated with silent brain infarctions, microbleeds and lesion locations. Int. J. Med. Sci 11(6), 587-592 (2014).

64. Wu RH, Li Q, Tan Y, et al. Depression in silent lacunar infarction: a cross-sectional study of its association with location of silent lacunar infarction and vascular risk factors. Neurol. Sci 35(10), 1553-1559 (2014).

65. Terroni L, Amaro Jr E, losifescu DV, et al. The association of post-stroke anhedonia with salivary cortisol levels and stroke lesion in hippocampal/parahippocampal region. Neuropsychiatr. Dis. Treat 11(1), 233-242 (2015).

66. Metoki N, Sugawara N, Hagii J, et al. Relationship between the lesion location of acute ischemic stroke and early depressive symptoms in Japanese patients. Ann. Gen. Psychiatry 15(1), 12 (2016).

67. Wei C, Zhang F, Chen L, et al. Factors associated with post-stroke depression and fatigue: lesion location and coping styles. J. Neurol 263(2), 269-276 (2016). 
68. Vataja R, Pohjasvaara T, Mäntylä R, et al. Depression-executive dysfunction syndrome in stroke patients. Am. J. Geriatr. Psychiatry 13(2), 99-107 (2005).

69. Ayerbe L, Ayis S, Rudd AG, et al. Natural history, predictors, and associations of depression 5 years after stroke: the South London Stroke Register. Stroke 42(7), 19071911 (2011).

70. Zavoreo I, Bašić-Kes V, Bosnar-Puretić M, et al. Post-stroke depression. Acta. Clinica. Croatica 48(3), 329-333 (2009).

71. Andersen G, Vestergaard K, Lauritzen L. Effective treatment of poststroke depression with the selective serotonin reuptake inhibitor citalopram. Stroke 25(6), 1099-1104 (1994).

72. Bruce ML. Depression and disability in late life: directions for future research. Am. J. Geriatr. Psychiatry 9(2), 102-112 (2001).

73. Mulsant BH, Ganguli M, Seaberg EC. The relationship between self-rated health and depressive symptoms in an epidemiological sample of community-dwelling older adults. J. Am. Geriatr. Soc 45(8), 954-958 (1997)

74. Morris PL, Shields RB, Hopwood MJ, et al. Are there two depressive syndromes after stroke? J. Nerv. Ment. Dis 182(4), 230-234 (1994).

75. Spencer KA, Tompkins CA, Schulz R. Assessment of depression in patients with brain pathology: the case of stroke. Psychol. Bull 122(2), 132 (1997).

76. Hackett ML, Anderson CS, House A, et al. Interventions for treating depression after stroke. Cochrane. Database. Syst. Rev (4), Cd003437 (2008)

77. Hackett ML, Anderson CS, House A, et al. Interventions for preventing depression after stroke. Cochrane. Database. Syst. Rev (3), Cd003689 (2008)

78. Janneke $M$, Hafsteinsdóttir T, Lindeman $E$ et al. An efficient way to detect poststroke depression by subsequent administration of a 9-item and a 2-item Patient Health Questionnaire. Stroke 43(3), 854-856 (2012).

79. Berg A, Lönnqvist J, Palomäki H, et al. Assessment of depression after stroke a comparison of different screening instruments. Stroke 40(2), 523-529 (2009).

80. Goldstein G, Condray R, Schramke CJ, et al. Poststroke depression and anxiety: different assessment methods result in variations in incidence and severity estimates. J. Clin. Exp. Neuropsychol 20(5), 723-737 (1998).

81. Townend E, Brady M, McLaughlan K. A systematic evaluation of the adaptation of depression diagnostic methods for stroke survivors who have aphasia. Stroke 38(11), 3076-3083 (2007).

82. Castillo CS, Starkstein SE, Fedoroff JP, et al. Generalized anxiety disorder after stroke. J.
Nerv. Ment. Dis 181(2), 100-106 (1993).

83. Zikic TR, Divjak I, Jovicevic M, et al. The effect of post stroke depression on functional outcome and quality of life. Acta. Clin. Croat 53(3), 294-301 (2014).

84. Cameron Jl, Cheung AM, Streiner DL, et al. Stroke survivor depressive symptoms are associated with family caregiver depression during the first 2 years poststroke. Stroke 42(2), 302-306 (2011).

85. Ramasubbu R. Therapy for prevention of poststroke depression. Expert. Opin. Pharmacother 12(14), 2177-2187 (2011).

86. Turner-Stokes L, Hassan N. Depression after stroke: a review of the evidence base to inform the development of an integrated care pathway. Part 1: Diagnosis, frequency and impact. Clin. Rehabil 16(3), 231-247 (2002).

87. Spalletta G, Bossu P, Ciaramella A, et al. The etiology of poststroke depression: a review of the literature and a new hypothesis involving inflammatory cytokines. Mol. Psychiatry 11(11), 984-991 (2006).

88. Banasr M, Duman RS. Regulation of neurogenesis and gliogenesis by stress and antidepressant treatment. CNS. Neurol. Disord. Drug. Targets 6(5), 311-320 (2007).

89. Castanon N, Leonard BE, Neveu PJ, et al. Effects of antidepressants on cytokine production and actions. Brain. Behav. Immun 16(5), 569-574 (2002).

90. Zhang LS, Hu XY, Yao LY, et al. Prophylactic effects of duloxetine on post-stroke depression symptoms: an open single-blind trial. Eur. Neurol 69(6), 336-343 (2013).

91. Rasmussen $A$, Lunde $M$, Poulsen $D L$, et al. A double-blind, placebo-controlled study of sertraline in the prevention of depression in stroke patients. Psychosomatics 44(3), 216-221 (2003).

92. Robinson RG, Jorge RE, Moser DJ, et al. Escitalopram and problem-solving therapy for prevention of poststroke depression: a randomized controlled trial. JAMA 299(20), 2391-2400 (2008).

93. Jorge RE, Robinson RG, Arndt S, et al. Mortality and poststroke depression: a placebocontrolled trial of antidepressants. Am. J. Psychiatry 160(10), 1823-1829 (2003).

94. Almeida OP, Waterreus A, Hankey GJ. Preventing depression after stroke: Results from a randomized placebo-controlled trial. $J$. Clin. Psychiatry 67(7), 1104-1109 (2006).

95. DeVane CL, Markowitz JS. Avoiding psychotropic drug interactions in the cardiovascular patient. Bull. Menninger. Clin 64(1), 49-59 (2000).

96. Fullerton A, Agerholm M. Side-effects of nortriptyline treatment for post-stroke depression. The Lancet 323(8375), 519-520 (1984).
97. Chen Y, Patel NC, Guo JJ, et al. Antidepressant prophylaxis for poststroke depression: a meta-analysis. Int. Clin. Psychopharmacol 22(3), 159-66 (2007).

98. Dwyer Hollender K. Screening, diagnosis, and treatment of post-stroke depression. J. Neurosci. Nurs 46(3), 135-141 (2014).

99. Jorge RE, Robinson RG, Arndt S, et al. Mortality and poststroke depression: a placebocontrolled trial of antidepressants. Am. J. Psychiatry 160(10), 1823-1829 (2003).

100. Bartoli F, Lillia N, Lax A, et al. Depression after stroke and risk of mortality: a systematic review and meta-analysis. Stroke. Res. Treat 2013:862978 (2013).

101. Robinson RG, Jorge RE. Post-Stroke Depression: A Review. Am. J. Psychiatry 173(3), 221-231 (2016).

102. Capaldi VF, Wynn GH. Emerging strategies in the treatment of poststroke depression and psychiatric distress in patients. Psychol. Res. Behav. Manag 3(1), 109-118 (2010).

103. El Husseini N, Goldstein LB, Peterson ED, et al. Depression and Antidepressant Use After Stroke and Transient Ischemic Attack. Stroke 43(6), 1609-1616 (2012).

104. Mortensen JK, Andersen G. Safety of selective serotonin reuptake inhibitor treatment in recovering stroke patients. Expert. Opin. Drug. Saf 14(6), 911-919 (2015).

105. Coupland C, Dhiman P, Morriss R, et al. Antidepressant use and risk of adverse outcomes in older people: population based cohort study. BMJ 343:d4551 (2011).

106. Wiese BS. Geriatric depression: The use of antidepressants in the elderly. BCMJ 53(7), 341-347 (2011).

107. Rampello L, Alvano A, Chiechio S, et al. An evaluation of efficacy and safety of reboxetine in elderly patients affected by "retarded" post-stroke depression: A random, placebo-controlled study. Arch. Gerontol. Geriatr 40(3), 275-285 (2005).

108. Price A, Rayner L, Okon-Rocha E, et al. Antidepressants for the treatment of depression in neurological disorders: a systematic review and meta-analysis of randomised controlled trials. J. Neurol. Neurosurg. Psychiatry 82(8), 914-923 (2011).

109. Paolucci S. Epidemiology and treatment of post-stroke depression. Neuropsychiatr. Dis. Treat 4(1), 145-154 (2008).

110. Broomfield NM, Laidlaw K, Hickabottom E, et al. Post-stroke depression: the case for augmented, individually tailored cognitive behavioural therapy. Clin. Psychol. Psychother 18(3), 202-217 (2011).

111. Jorge RE, Robinson RG, Tateno A, et al. Repetitive transcranial magnetic stimulation as treatment of poststroke depression: a preliminary study. Biol. Psychiatry 55(4), 398- 


\section{Review Ali Mahmood Khan}

405 (2004).

112. Murray GB, Shea V, Conn DK. Electroconvulsive therapy for poststroke depression. J. Clin. Psychiatry 47(5), 258260 (1986).

113. Van der Wurff F, Stek M, Hoogendijk W, et al. The efficacy and safety of ECT in depressed older adults: a literature review. Int. J. Geriatr. Psychiatry 18(10), 894-904 (2003)

114. Lipsey J, Pearlson G, Robinson R, et al. Nortriptyline treatment of post-stroke depression: a double-blind study. Lancet 323(8372), 297-300 (1984).

115. Reding MJ, Orto LA, Winter SW, et al. Antidepressant therapy after stroke: a double-blind trial. Arch. Neurol 43(8), 763765 (1986).

116.Andersen G, Vestergaard K, Lauritzen L. Effective treatment of poststroke depression with the selective serotonin reuptake inhibitor citalopram. Stroke 25(6), 1099-1104 (1994).

117. Grade C, Redford B, Chrostowski J, et al. Methylphenidate in early poststroke recovery: a double-blind, placebocontrolled study. Arch. Phys. Med. Rehabil 79(9), 1047-1050 (1998).

118. Robinson RG, Spalletta G. Poststroke depression: a review. Can. J. Psychiatry 55(6), 341-349 (2010).

119. Wiart L, Petit $\mathrm{H}$, Joseph $\mathrm{P}$, et al. Fluoxetine in early poststroke depression. Stroke $31(8), 1829-1832$ (2000)

120. Fruehwald S, Gatterbauer E, Rehak P, et al. Early fluoxetine treatment of post-stroke depression. J. Neurol 250(3), 347-351 (2003)

121. Choi-Kwon S, Han SW, Kwon SU, et al. Fluoxetine Treatment in Poststroke Depression, Emotional Incontinence, and Anger Proneness. Stroke 37(1), 156-161 (2006).
122. Kucukalić A, Bravo-Mehmedbasić A, Kulenović $A$, et al. Venlafaxine efficacy and tolerability in the treatment of post-stroke depression. Psychiatr. Danub19(1-2), 56-60 (2007).

123. Li LT, Wang SH, Ge HY, et al. The beneficial effects of the herbal medicine Free and Easy Wanderer Plus (FEWP) and fluoxetine on post-stroke depression. J. Altern. Complement. Med 14(7), 841-846 (2008).

124. Cravello L, Caltagirone C, Spalletta G. The SNRI venlafaxine improves emotional unawareness in patients with post-stroke depression. Hum. Psychopharmacol 24(4), 331-336 (2009).

125. Mikami K, Jorge RE, Adams HP, et al. Effect of antidepressants on the course of disability following stroke. Am. J. Geriatr. Psychiatry19(12), 1007-10015 (2011).

126. Hackett ML, Yang M, Anderson CS, et al. Pharmaceutical interventions for emotionalism after stroke. Stroke 41(7), e460-e1 (2010).

127. Sunami E, Usuda K, Nishiyama Y, et al. A preliminary study of fluvoxamine maleate on depressive state and serum melatonin levels in patients after cerebral infarction. Int. Med 51(10), 1187-1193 (2012).

128. Huang $\mathrm{H}$, Chen $\mathrm{K}$, Guo $\mathrm{T}$, et al. Treatment with carotid angioplasty stent placement for post-stroke depression compared to antidepressants. Neurosciences 17(1), 53-56 (2012).

129. Man SC, Hung BH, Ng RM, et al. A pilot controlled trial of a combination of dense cranial electroacupuncture stimulation and body acupuncture for post-stroke depression. BMC. Complement. Altern. Med 14(1), 255 (2014).

130. Hu Y, Xing H, Dong $X$, et al. Pioglitazone is an effective treatment for patients with post-stroke depression combined with type 2 diabetes mellitus. Exp. Ther. Med 10(3), 1109-1114 (2015).
131. Kootker JA, Rasquin SM, Smits $P$, et al. An augmented cognitive behavioural therapy for treating post-stroke depression: description of a treatment protocol. Clin. Rehabil 29(9), 833-843 (2015).

132. Yan D, Shan J, Ze Y, et al. The effects of combined hyperbaric oxygen therapy on patients with post-stroke depression. J. Phys. Ther. Sci 27(5), 1295-1297 (2015).

133. van Eeden M, Kootker J, Evers S, et al. An economic evaluation of an augmented cognitive behavioural intervention vs. computerized cognitive training for post-stroke depressive symptoms. BMC. Neurology 15(1), 266 (2015).

134. Valiengo LC, Goulart AC, de Oliveira JF, et al. Transcranial direct current stimulation for the treatment of post-stroke depression: results from a randomised, sham-controlled, double-blinded trial. $J$. Neurol. Neurosurg. Psychiatry 88(2), 170175 (2017).

135. Murray V, Arbin Mv, Bartfai A, et al. Double-blind comparison of sertraline and placebo in stroke patients with minor depression and less severe major depression. J. Clin. Psychiatry 66(6), 708 716 (2005).

136. Kim JM, Stewart R, Bae KY, et al. Serotonergic and BDNF genes and risk of depression after stroke. J. Affect. Disord 136(3), 833-840 (2012).

137. Burns MM, Greenberg DA. Antidepressants in the treatment of stroke. Exp. Rev. Neurotherap 10(8), 1237-1241 (2010).

138. Yi Z, Liu F, Zhai S. Fluoxetine for the prophylaxis of poststroke depression in patients with stroke: a meta-analysis. Int. J. Clin. Practice 64(9), 1310-1317 (2010).

139. Meader N, Moe-Byrne T, Llewellyn A, et al. Screening for poststroke major depression: a meta-analysis of diagnostic validity studies. J. Neurol. Neurosurg. Psychiatry 85(2), 198-206 (2014). 